\title{
The Impact of COVID-19 on the Internationalization of Higher Education
}

\author{
Simon Kanjera ${ }^{1}$ \\ ${ }^{1}$ Faculty of Applied Social Sciences, Zimbabwe Open University, Zimbabwe \\ Correspondence: Simon Kanjera, Faculty of Applied Social Sciences, Zimbabwe Open University, Zimbabwe.
}

Received: March 2, 2021

Accepted: April 10, 2021

Online Published: April 22, 2021

doi:10.5430/irhe.v6n1p25

URL: https://doi.org/10.5430/irhe.v6n1p25

\begin{abstract}
The COVID-19 pandemic has posed new challenges to global higher education, and higher education institutions have made innovations in teaching methods, student management and evaluation mechanisms. At a time when huge efforts have been made to transform and improve higher education in Africa, the COVID-19 pandemic could destabilize the higher education sector with serious consequences. This paper focuses on some of these implications in order to enable higher education leaders, decision makers, and other stakeholders to reflect and prepare adequately to address these issues.
\end{abstract}

Keywords: COVID-19, internationalization, higher education

\section{Introduction}

The COVID-19 pandemic is upending economies, higher education and the lives of millions of people across the globe. For example, universities are closed, classes are cancelled or online, and meetings are cancelled. Directly related to international higher education, prospective students have been unable to take exams and various study abroad programs have been cancelled. International students are unable to travel to campus or return home. Faculty members have been asked not to travel to hard-hit countries or have been asked not to travel abroad.

As the NOVEL coronavirus spreads to more countries and affects more people, the direct effects and inconveniences are likely to increase. But what will be the medium - to long-term impact of this crisis on international higher education? Overall, we do not think the impact is significant. Instead, some educators see positive effects of the crisis on international higher education: an increase in online teaching and the associated reduction in the carbon footprint. International student enrollment policies have become more diverse, thus reducing dependence on major exporting countries for international students.

There is no doubt that higher education mobility will decline over the next year or so. China will remain the world's largest sender of students for the foreseeable future, but the number of students from the country is likely to decline significantly in the short term, though not dramatically in the long term. After the end of the pandemic, the mobility pattern of international higher education is likely to be restructured. Iran used to be a major contributor, but it no longer plays a major role. Similarly, Brazil and Saudi Arabia have declined in their status as sending countries, while Vietnam and India have risen. In the future, many of the students will also come from Africa -- mainly Nigeria and Kenya.

Destinations for students are shifting from Europe, North America and Australia to Asia and the Middle East. We speculate that the total number of international students may decrease and that preferred destinations may change. The United States, in particular, may decline as the destination of choice, but the traditional pattern of international study will continue. Some lesser-known universities in Australia, Britain and the United States have come to rely on international students, seeing their fees as an important part of their income. And the COVID-19 pandemic is increasingly reminding higher education institutions that relying too heavily on tuition fees from international students can be a major problem.

Some universities that have closed their campuses are using distance learning to teach, and it is really impressive how much experience they have gained with some results. However, we are still skeptical about the quality of education and student satisfaction. Because most teachers around the world are not trained in distance learning, do not have the cutting-edge technology necessary to deliver high-quality instruction, and do not adapt curricula in time 
to meet the needs of online learning. In Boston college's experience, creating an interactive and effective online classroom environment is extremely difficult due to technical limitations, lack of experience, and lack of suitable equipment. While it is possible to teach and learn effectively online, it takes time and support. Making these changes quickly is bound to lead to lower quality, and the quality of learning deteriorates further when students lack access to online education facilities. Hence, we should not idealize the current online curriculum.

Some believe that degree programs aimed at international students may increasingly move to an online model, though only with some success in continuing education. For the most part, international students will continue to prefer the experience of studying in another country, and many will seek jobs overseas when their studies are over. While thousands of students have been called home from study abroad programs of one semester or less, short-term programs are unlikely to suffer deep cuts in the long term. The trend to seek shorter periods of mobility (less than eight weeks) and to rely on more "safe" countries is likely to continue to strengthen. France and Spain recovered their status as leading countries to study soon after their own terrorist attacks, and Italy may be about to do the same. The epidemic is a severe test for society, higher education and individuals, but the epidemic will pass, and the internationalization of higher education may soon return to its former status.

Simon Kinson, Professor of Education at the University of Oxford and Director of the Centre for Global Higher Education Research at the University of Oxford: The COVID-19 pandemic will reshape global higher education. While it is too early to draw conclusions about the impact of COVID-19 on student mobility and international education provision, we have enough information to make the following five judgments.

First, from the perspective of biology and globalization, the international education sector will be hit hard by a global epidemic that affects population mobility. Countries and universities that are financially dependent on international students will face a huge financial gap that some of them will not be able to fill on their own. Second, while the shift to online education will have a lasting impact, it will also be affected by the duration of the pandemic. Third, the outbreak occurred in different countries at different times, and their governance policies and health systems are also different. The countries of origin of students are also affected to different degrees. The recovery of countries will be staggered and uneven, which will affect the future flow of students. Fourth, in the process of recovery, international education will turn into a buyer's market, where international students are scarce and competition for international students will be fiercer. Fifth, a country's reputation for health care and emergency aid, as well as health and safety issues, will become more important as students choose their destination.

\section{Educational Equity and Teaching Quality}

As part of lockdown measures aimed at containing the spread of COVID-19, African countries had no choice but to close their institutions of higher learning, and institutions had no choice but to turn to information and communication technology (ICT) to deliver courses online to school students. But the process has exposed a digital divide within the continent: some countries have better infrastructure than others; Some institutions of higher learning in the same country are better equipped and better experienced than others; Between students at the same university -- affluent students living in cities and poor students living in rural areas -- the former can use the Internet while the latter can hardly afford it. Indeed, the crisis has provided an opportunity for all higher education institutions to rapidly improve and maximize their ICT operations. But most higher education institutions lack the ability to offer classes fully online. Although there are few open universities in Africa with this capability, they cater mainly to those who are already employed and who want to improve their education. While many African institutions of higher learning have been implementing blended learning (a mix of face-to-face and online learning) in an effort to increase opportunities and improve learning, few institutions intend to completely replace face-to-face instruction.

Then, in a relatively short period of time, how are African countries and higher education institutions coping with the inequalities created by the widespread use of online learning? It is a fallacy to think that online learning can be effective simply by Posting a faculty member's notes online or recording a video of a lecture. Yet this is what is generally happening now. Experience has shown that high-quality online learning requires textbooks written by professional instructional designers, instructors who teach the course trained in teaching methods, and students exposed to online teaching. Unprepared online delivery will have an impact on the quality of the course. This is unfortunate at a time when significant achievements have been made in improving the quality of teaching in African institutions of higher education. The courses most affected will be science and technology, as students will not have access to laboratories.

However, the curriculum of science and technology is the most important for Africa's development. How can institutions of higher learning find alternative ways to use laboratories, and then mitigate the consequences of poor quality courses as a result of unplanned online delivery? At present, secondary schools, which train and send students 
to higher education institutions, are also closed. It has been observed in many African countries that measures taken to increase access have resulted in a substantial increase in secondary school enrolment and, as a result, a decline in the quality of students attending higher education institutions. The situation will worsen as schools close, and institutions will have to come up with measures to cope with a poor pool of students, perhaps by offering remedial courses in the first year. High school graduation exams have also been postponed or cancelled. In the absence of test results, what should higher education institutions use in selecting their next cohort of students? Here, a nationwide education sector-wide response is needed.

\section{Scientific Research}

Many initiatives and projects have been launched over the past decades at the national, regional and continental levels to improve research outcomes in Africa. These initiatives and projects will focus on increasing the training of graduate students, particularly doctoral students, and, in some institutions of higher education, on research projects that have taken priority in the development process in Africa. Indicators show that these initiatives have achieved positive results. However, most of the funding for research initiatives has been provided by organizations and foundations in the US and Europe, and more recently by Chinese organizations and foundations. In The African region, there are few national institutions that fund research, and almost no regional or continental-wide institutions that fund research. Almost all research is conducted in collaboration with higher education institutions in European, American and Chinese countries. With THE COVID-19 pandemic hitting the world, European countries, the United States and China seem to be hardest hit. Can Africa continue to rely on state-sourced research funding? So how to sustain externally funded research that has been initiated in Africa? What alternative sources of funding can African higher education institutions turn to continue their research?

In most countries around the world, the most likely scenario is that the outbreak will last much longer than in China, Japan and South Korea, where governments have conducted comprehensive testing and tracking of COVID-19 cases, controlled population movements and improved health care. Although some countries have begun to impose "lockdown" measures, western European countries are moving slowly and facing a major outbreak of COVID-19.English-speaking countries are paying the price for their inadequate lockdown measures. Meanwhile, India, Pakistan, Bangladesh, Nepal and much of Africa are doing even less than Europe.

The duration of the outbreak will be longer, thanks to various "containment" strategies designed to flatten the case curve, reduce mortality and reduce pressure on health systems. Under these circumstances, with the exception of East Asia, it is unlikely that normal face-to-face teaching will begin in September-October 2020 in the northern hemisphere, with Australia and New Zealand likely to resume normal higher education in March 2021, with students in the northern hemisphere returning to university at that time or a little later. If the next school year begins with online adaptations, the quality requirements of online education platforms will be higher than the tentative adaptations that are currently in place.COVID-19 will accelerate the growth of online education, which is no longer seen as an adjunct to the traditional classroom, or as an inefficient imitation of face-to-face teaching, but as a unique form or product of higher education that can be used in a different way.

\section{Unemployment of Graduates}

Almost all African countries have recently faced the challenge of graduate unemployment, and in some cases the figures are staggering. According to feedback from employers, one of the main causes of unemployment is graduates' lack of "soft skills," including poor communication skills, lack of initiative and an inability to work in teams. Widespread use of online learning in the COVID-19 pandemic will undoubtedly exacerbate unemployment, as students will be studying alone, and this is an opportunity for employers to be actively involved and help provide the skills they need. Unfortunately, for various economic reasons, many potential private employers may be forced to lay off workers, thereby increasing the number of unemployed, which will make it more difficult for graduates to find a job. The social and political consequences of mass unemployment, especially among educated youth, can be severe.

\section{Possible Solutions}

A characteristic feature of the higher education sector in African countries is the existence of a variety of private higher education institutions. These institutions have greatly outnumbered public institutions of higher education, and enrollment in private institutions of higher education has increased steadily in recent years, so that in some countries almost equal numbers of students are now attending public and private institutions of higher education. These private higher education institutions often operate on a business model and rely heavily on student tuition to cover staff salaries and operating expenses. Public higher education institutions will eventually receive government support to overcome the consequences of COVID-19, but private higher education institutions may be forced to 
cease operations due to lack of funding, and closing these institutions will have a significant impact on the higher education sector and the economic development of countries. So what are the possible solutions? How should governments assist private higher education institutions in such a crisis?

Currently, African countries and the rest of the world are prioritizing strengthening the health sector in order to minimize the number of infections and limit the number of deaths, as well as finding ways to help vulnerable groups in their societies. While economic recovery and support for other sectors will have to come later, it is vital that each sector begins to reflect on the impact of COVID-19 and assess its likely impact. The same applies to the higher education sector, where the response must be holistic and accessible to all stakeholders, including the private sector. Each country should set up a higher education task force, led by the relevant authorities, to investigate the situation, propose immediate and short-term measures, and be prepared to take remedial measures when the crisis is over.

\section{Conclusions}

There will be no reduction in the need for face-to-face teaching in the future. Organized classrooms have irreplaceable advantages, but some universities with poor teaching quality will switch to online education altogether. The key issue is that once the scale of global demand for higher education recovers and the immediate restrictions on mobility and collective gatherings are lifted, the impact of the decline in global GROSS domestic product on students' ability to pay tuition fees, travel costs and living expenses will be decisive. The global middle class will shrink significantly for a while, especially in emerging economies. The number of mobile students around the world will also fall. It could take five years or more for the number of mobile students globally to return to 2019 levels.

As with all large-scale social changes, the gradual emergence of their effects will vary. In this case, the normal "iron law" -- that in a competitive situation the strongest person has an advantage -- would be modified by a variety of national policy factors. English-speaking countries will continue to be a strong attraction in global higher education for the foreseeable future, while East Asian countries are rising. East Asian countries, with their rising economies and strong health and governance systems, are set to rise further in international education. Higher education in countries such as the UK, US and Australia will not recover as quickly from the pandemic as in Japan, China and South Korea, which means that some of the western flows will shift to East Asian flows, and some of the changes will be permanent. At the same time, the negative medical and economic impact of the epidemic will be greatest in South Asia and sub-Saharan Africa, and the recovery time for students from these countries will be the longest.

A buyer's market has all sorts of new rules. If, for example, the number of Chinese students coming to the UK falls, it is unlikely that even an increase in Indian students will make up the shortfall. But much depends on the specific policies each country has in place to promote inward-looking student mobility and global engagement. For example, scholarship system, exchange programs similar to the Erasmus program, visa system, funding for students' accommodation, work, welfare and health, promotion of international education in specific countries of origin, etc. In the future, all policies and strategies will be reconsidered, leading to a very challenging new world.

\section{References}

Bozkurt, A., \& Sharma, R. C. (2020). Emergency remote teaching in a time of global crisis due to coronavirus pandemic. Asian Journal of Distance Education, 15(1), i-vi. https://doi.org/10.5281/zenodo.3778083

Hodges, C., Moore, S., Lockee, B., Trust, T., \& Bond, A. (2020). The difference between emergency remote teaching and online learning. Educause Review. Retrieved from https://er.educause.edu/articles/2020/3/the-difference-between-emergencyremote-teaching-and-online-learning

Karakose, T. (2020). Global Education in the shadow of the novel coronavirus: Reflections on the impact of COVID-19 outbreak on education systems. Educational Process: International Journal, 9(4), 201-204. https://doi.org/10.22521/edupij.2020.94.1

Karakose, T., \& Kocabas, I. (2006). The effect of teachers' expectations on job satisfaction and motivation in private and public schools. Journal of Theory and Practice in Education, 2(1), 3-14. Retrieved from https://dergipark.org.tr/en/pub/eku/issue/5441/73869

Karakose, T., \& Malkoc, N. (2021a). Behavioral and interpersonal effects of the COVID-19 epidemic on frontline physicians working in Emergency Departments (EDs) and Intensive Care Units (ICUs). Acta Medica Mediterranea, 37, 437-444. https://doi.org/10.19193/0393-6384_2021_1_68

Karakose, T., \& Malkoc, N. (2021b). Psychological impact of the COVID-19 pandemic on medical doctors in Turkey. Social Behavior and Personality, 49(1), e9890. https://doi.org/10.2224/sbp.9890

Karakose, T., Kocabas, I., Yesilyurt, H. (2014). A quantitative study of school administrators' work-life balance and 
job satisfaction in public schools. Pakistan Journal of Statistics, 30, 1231-1241. Retrieved from https://www.researchgate.net/publication/289002648_A_quantitative_study_of_sch

Noor, S., Isa, F. Md., \& Mazhar, F. F. (2020). Online teaching practices during the COVID-19 pandemic. Educational Process: International Journal, 9(3), 169-184. https://doi.org/10.22521/edupij.2020.93.4

Pokhrel, S., \& Chhetri, R. (2021). A literature review on impact of COVID-19 pandemic on teaching and learning. Higher Education for the Future, 8(1), 133-141. https://doi.org/10.1177/2347631120983481

Ren, L.-L., Wang, W.-M., Wu, Z.-Q., Xiang, Z.-C., Guo, L., Xu, T., ... Wang, J.-W. (2020). Identification of a novel coronavirus causing severe pneumonia in human: A descriptive study. Chinese Medical Journal, 133(9), 1015-1024. https://doi.org/10.1097/CM9.0000000000000722

Tesar, M. (2020). Towards a post-Covid-19 "New Normality?": Physical and social distancing, the move to online and higher education. Policy Future in Education, 18(5), 556-559. https://doi.org/10.1177/1478210320935671

World Health Organization. (2020). Naming the coronavirus disease (COVID-19) and the virus that causes it. Retrieved

from https://www.who.int/emergencies/diseases/novel-coronavirus2019/technical-guidance/naming-the-coronavirusdisease-(covid-2019)-and-thevirus-that-causes-it

Zhang, W., Wang, Y., Yang, L., \& Wang, C. (2020). Suspending classes without stopping learning: China's education emergency management policy in the COVID-19 outbreak. Journal of Risk and Financial Management, 13(55), 1-6. https://doi.org/10.3390/jrfm13030055

Zhu, N., Zhang, D., Wang, W., Li, X., Yang, B., Song, J., ... Tan, W. (2020). A novel coronavirus from patients with pneumonia in China, 2019. The New England Journal of Medicine, 382(8), 727-733. https://doi.org/10.1056/NEJMoa2001017

\section{Copyrights}

Copyright for this article is retained by the author(s), with first publication rights granted to the journal.

This is an open-access article distributed under the terms and conditions of the Creative Commons Attribution license (http://creativecommons.org/licenses/by/4.0/). 